\title{
Media Presentation of Violence that Occurs Due to Dissatisfaction and Communication Difficulties between Health Personnel and Patients and/or their Relatives*
}

\author{
Rüçhan Gökdağ, Anadolu University, Turkey
}

\begin{abstract}
The rise in Turkish people's violent behaviors has extended to health workers as well and news on physical assaults and fatalities has begun to be reported occasionally by the media. Yet -as it always does- because of the dramatization and tabloidization of violence by media, the violence problem has been trivialized by digressing from the heart of the matter. This study is about how violence news about health workers is reported in newspapers. For this purpose, 34 news reports related to health area in two internet sites were analyzed. News was analyzed with the dimensions of the actors, news sources, places where violence happened, the reason of the violence and the metaphors used.
\end{abstract}

According to the results; news texts are prepared with the information collected by correspondents. No expert opinions were cited in one third $(35,2 \%)$ of the news, and the only information source about the violence was the doctor who had been subject to violence. The violence occurred mostly in state hospitals (50\%), followed by112 Emergency Ambulance Service $(32,3 \%)$. The main reason of the violence was dissatisfaction with the doctor's diagnosis and his/her clinical interventions. The reporting style was sensational and tabloidized. Many metaphors were used in the news.

Keywords: Violence, health worker, liberal approach, critical approach

\footnotetext{
*This article is the expanded and revised version of the paper presented at the International Conference on Global Health Crisis Communication hosted by the Faculty of Communication Sciences of Anadolu University in June 2012.
} 


\section{Introduction}

In recent years, the violent news in the Turkish media has been on the rise so much so that, due to the way they happen or the actor(s) involved in such violent acts, they may occupy the public agenda for days on end. It's almost as if the Turkish people are living day in and day out with extremely worrisome news and images of violence broadcast to their homes. Besides increasing in their number, these news reports also vary greatly by the type of violence, scene, perpetrators and the method they report. In this regard, health workers may face all kinds of violence including threats, physical assaults, physical injury, and even death. The institutions that distribute health to people are themselves having serious trouble protecting their own workers' health and safety. Today, health workers live in anxiety and fear (SağlıkSen, 2013).

Just as violence is a grave problem for the Turkish society, its presentation in the media poses another problem. Although, as a mass communication medium, newspapers had the opportunity to report more comprehensive and detailed news that radio and television do not/ cannot, in time they have increasingly become like them. The dramatized style of news reporting that we are now so much used to see on TV news has also begun to be copied by the press. The presentation of news in such dramatized way helps increase the readability but at the same time trivializes and pushes the content to the background, however serious it might be (Baytar, 2005). This study focuses on how the violence arising from the communication problems between health workers and patients/patient relatives is reported in newspapers.

\section{Violence against Health Workers}

The violence in health institutions is described as, "committed by the patient, the relatives of the patient or another perpetrator, the verbal or behavioral threat and physical or sexual assault that poses a risk for the health worker" (Saines, 1999).

The research on violence against health workers shows that the violence occurring in this sector is more frequent than other sectors. However, since only the serious cases like battery and bodily injury are officially reported, the actual gravity of the problem in health institutions remains hidden from view (Barret, 1997; Gates, 1995, in Annagün, 2010). This means that the verbal violence does not usually get officially reported or documented. 
According to another study, the violence risk faced by health workers is 16 times as high as the workers in other institutions (Elliott, 1997, in Annagün, 2010).

According to the findings of a survey that was carried out in 2013 with 1300 health employees in 25 cities by SağlıkSen (Health Workers' Union); four in every five health workers $(81,9 \%)$ are concerned about facing violence at their workplaces. $86,8 \%$ of the participants were subject to violence at least once in their career (SağlıkSen, 2013). These figures reveal how alarming the degree of violence in the health sector has become. According to the results of the same survey, when the rate of violence risk for the health workers is analyzed geographically on the basis of the seven major regions of Turkey, it was found to be higher for the South Eastern Anatolia Region than the other six regions and statistically significant as well. Many other studies on the subject (Aydın, 2008; Ergur, 2009; İlhan et al., 2009; Özcan et al., 2011) indicate that the health staff that are subjected to violence most frequently are doctors and nurses, respectively. In another study that was conducted in health institutions in three cities in 2002,those who encounter violence are shown to be mostly general practitioner doctors and nurses and the most common places for such violent acts are the emergency services of state hospitals (Ayranc1 et al., 2002). Another finding from the same study is that the workers do not get any help when they experience violence. A study carried out by Erkolet al. (2007) shows that the perpetrators of violence are aged 21-30, with lower status of education. The violence is committed either by the patient relatives alone or acting together with the patients. While much less frequent, sometimes the patient may act violently on his/her own as well.

\section{Two Different Approaches to News}

The scientific work in reporting news is conducted along two basic axes. These are liberal and critical approaches. The basic characteristics of these two approaches are summarized below.

\section{Liberal Approach}

Originating in the US, this approach, this type of news and journalism was derived from the liberal theory. According to this approach, news media is a power that monitors the executive, legislative and judicial powers that constitute the foundation of democratic systems for the good of public. In the cases where public interests are not favored, - to watch 
over the public interest -this institution has the responsibility to warn or at least should do so. According to the liberal approach, by being aware of their social responsibilities, media professionals carry out their public missions as per the principles of objectivity, impartiality and fairness. They can achieve this by remaining at an equal distance from the news event in question and the people involved in the news (Özer, 2010). It is assumed that the journalist can reflect the events and phenomena just like a mirror does. This concept is called "liberal media theory".

Liberal Media Theory is based on the social, philosophical and economic foundations of the 17 th century liberal perspective. In this period, the classical democracies just started to consolidate, state intervention into the economic life was restricted and the individuals were given various rights and freedoms. One of these freedoms is the freedom of speech and thought. Situating the individual, rather than the state, in the center, the liberal approach holds that only if individuals can think freely they can solve their own problems (Işı1k, 2002). The liberal approach is predicated on the idea that all kinds of opinions and truths should be expressed freely and communication of thought should be freely carried out. The means to ensure such free communication must be used according to the pluralism concept. Pluralism, which is the expression of liberal communication, is accepted as a tool to reach truth and achieve objectivity (Kaya, 1985).

News objectivity (impartiality) is grounded on the positivism in social sciences: It is accepted that, just like scientists, journalists can approach the subject or news topic that they are working on by getting rid of all sorts of personal judgments and ideologies. It is also accepted that objectivity can be achieved on the condition that certain rules are followed in the processes of collection and reporting of news information. Objectivity is a condition that can be achieved by allowing equal coverage to the parties of the news incident (Dursun, 2005; Atabek, 1994), that is, by giving equal time and length for the explanations, requiring compliance with the balance principle. Reporting news from a balanced perspective, from third person point of view and by using present tense are the rules that are deemed by the liberal news production as the prerequisites for objectivity. Therefore, news is a distinct genre among all other types of media. It is different from other literary genres such as novel, story and poem in that the news language and discourse must be based on professional principles. This happens only in news texts (İnal, 1996; Bertrand, 2004). 


\section{Critical Approach}

The critical approach, which critically handles news within the Marxist epistemology, has a completely different perspective from the liberal news concept. According to the critical approach, neither do the news texts reflect the truth as is, nor is the news reporter or the journalist a medium between the event and public. This cannot happen because media, operating in a capitalist society, must side with certain class-based interests, which renders objective and impartial journalism impossible.

Dursun (2003) argues that due to the nature of truth, a journalist cannot reflect the truth, because knowing the truth is not the truth itself. Knowledge is just a representation of the truth. For example, a photo of a war is not the same as the war itself. Therefore, the journalist is not someone reflecting the truth as is, but the producer of a text - a news text representing it. During the writing process, what is to be included and excluded in the news text is a preference.

Since news production practices are constructed, news is also a constructed type of information. This view led news theorists to analyze both the production processes and how the resulting (news) text elements are related together. Thus, news has been subject to deconstruction as a constructed text.

The struggle to understand life as it is lived, which is the focus of cultural studies, has developed by taking into account the complexity of experience within a certain social structure and situating ideology in the center. The subject of meaning and ideology is analyzed in an interrelated way without reductionism, and the social structure is seen as the field of meanings that are produced by culture and ideology (Dursun 2003; Özer, 2010).

In the Cultural Studies approach, the emphasis put on ideology as the creator of social meaning directed towards the construction of subject has allowed its tangible materialization in some contexts to be analyzed. Most prominent of these are the mass communication media. Mass communication media have drawn enormous interest as the environments allowing an analysis of what meaning and subjectivities are constructed for the reproduction of certain power relations (Dursun 2003; İrvan, 1995; Bertrand, 2004). 
The construction of "dominant ideology" in texts and questioning the dominant position of texts in the reception process provide the basic paradigm for the conceptualization of power/government problem within cultural studies (İnal, 1995).

News media are the tools whereby social power/government is constructed-built. As one of the profitable institutions within capitalist economy, new media remains dependent on power/government people or organizations in sustaining the existing power/government relations instead of being the social fourth power (İnal, 1995).

According to Hall (1999), media tend to reproduce the interpretations that serve the interests of the dominant class. These interpretations are also ideological battlefields. Media's system of meanings is accepted as relatively autonomous. Granted, "news", plays an important by completing the events; but compared to the authorized sources like media, government and other institutions they are secondary descriptors. Since media primarily use these institutions as their resources, they are the secondary descriptors. Therefore, Hall assert that dominant discourses are reconstructed in the news text (translated by Küçük, 1999).

What is emphasized in the context above is that, the news discourse is not independent from the discourses of the dominant discourse, that is, from the discourses of the institutions that hold power/government. News depends on the presentation of selected "other" people's opinions and these people reflect the opinions of the institutions that have power. Hall defines these people as "primary descriptors". Journalists are the "secondary descriptors" that convert the situation descriptions of the primary descriptors into lay people's language (İnal, 1995).

Beginning to research the professional journalism codes and institutional bureaucratic mechanisms that are effective on the news production processes that are used until they reach the viewers/readers as news afforded the communication/news studies to have another important insight. This insight is the emerging awareness that the professional codes of journalism are themselves ideological (Soloski, 1999). Here this role refers to the reproduction and masking of inequality that already exists within society that results from the power relationship that is established with the news sources. Journalists' relationships with their sources and particularly their reliance on official institutions and organizations are pointed as problematic due to the ideological roles that their news serve. 
Aim

The aim is to identify the media presentation of violence arising from communication difficulties and dissatisfaction between health personnel and patient and/or patient relatives. In line with this overall aim, news on violence is analyzed with its following dimensions:

- Actors of violence

- News sources

- Places

- Reason for the incident

- Use of metaphor

\section{Method}

In this study the document analysis method is used. It determines the status of the research topic. The way violence against health staff is handled in print media has been attempted to be revealed. The study covers the period between 15.04.2012 and 15.06.2012, and comprises the news regarding violence against health workers reported by the websites http://www.personelsaglik.com.tr/ and http://www.saglikcilar.net/. 34 news texts reported by these websites have been analyzed on the basis of the five analysis dimensions given in the aim section.

\section{Findings and Discussion}

For 34 news reports on http://www.personelsaglik.com.tr/ and http://www.saglikcilar.net/health websites, as can be seen in Table 1, information from six different sources has been used.

According to Table 1, over two thirds of the news on violence $(71 \%)$ is prepared by using the news reporter's reports and/or the information coming from agencies. This indicates that opinions of an expert or a professional organization on the experiences violence are not sufficiently included in the preparation of the news. However, the primary reason reported by the perpetrators of the violent acts being dissatisfaction about the diagnosis 
Table 1. Who/where the news source is

\begin{tabular}{lcc} 
News source & Number & $\%$ \\
\hline Reporter & 26 & 68,4 \\
Doctor & 6 & 15,8 \\
Agency & 1 & 2,6 \\
Union representative & 2 & 5,3 \\
Chamber of Physicians & 1 & 2,6 \\
Health staff & 2 & 5,3 \\
\hline T OTAL & 38 & 100,0
\end{tabular}

and/or the method of treatment increases the importance of consulting an expert or professional organization opinion on the matter. Due to the fact that health is a field that requires specialization, benefiting from the opinions of such professional organization representatives or expert scan make news more impartial and truthful. Nevertheless, when the source of opinion for the reported news is the doctor or the health staff that has been exposed to violence, this poses two risks. First; since the person exposed to violence is a party in the incident, the information and assessment he or she provides may be partial. Second, the explanations and images of the person experiencing the violence may be used by the reporter to tabloidize the violent incident.

People exposed to violence: According to the explanations in the analyzed 34 news reports, around two thirds of the health staff that were exposed to violence $(61, \% 8)$ are doctors. This is a natural result because it is always the doctor that first encounters the patient and his or her relatives, that diagnoses and decides about and initiates the proper way of treatment, and gets in contact with the patients and the relatives to provide all kinds of medical information to them. The remaining $38,2 \%$ of the personnel that experience violence are other health personnel(nurse, caregiver, etc.).These findings are similar to the ones found by Aydın, 2008; Ergur, 2009; İlhan et al., 2009; Özcanet al., 2011. 
Table 2. The person exposed to violence

The person exposed to violence

Doctor

Other health personnel
Number \%

$21 \quad 61,8$

$13 \quad 38,2$

TOTAL

$34 \quad 100,0$

Those who apply violence are mostly the relatives of the patient or patients themselves (46\%). This finding correlates with the findings of the study conducted by Erolet al. (2007) as well.

Places where violence is applied: According to Table 3, the place that violence most frequently occurs is state hospitals (50\%). Second most frequent site of violence is 112 Emergency Ambulance Services (32,3\%).

Table 3. Places where violence is applied

Place

State hospital

112 Emergency Ambulance Service

Private hospital

Other

TOTAL
Number \%

$17 \quad 50,0$

$11 \quad 32,3$

$4 \quad 11,8$

$2 \quad 5,9$

$34 \quad 100,0$

As the scenes of violence, ranking third with the lowest occurrence rate is private hospitals (11.8\%). State hospitals and 112 Emergency Services are easily accessible and open to everybody. This may be interpreted as a facilitative factor in violence. Conversely, not being 
free of charge and employing private security personnel, private hospitals can be said to have a deterrent effect against violence. Similarly, since the services in faculties of medicine are not easily accessible, cases of violence are less frequent in these places.

Causes for violence: When the causes of violence in Table 4 are analyzed, it is clear that each is a situation that is highly difficult, heavy, and hard to bear for people. In such conditions, people experience intensive emotions and usually rage often follows such sorrow (McLaren, 2011).

While the reasons given in Table 4 appear individual, actually it can be said that the national health policy, the quality of the offered services, the adequacy of the number of service providers and the conditions of the treatment environments may also play a role. Thus, the reason of experienced violence cases is not only the perception that the doctor's service is problematic or the individuals are angry. The real problem is that in Turkey people have many problems including hospital and medical services and that these are experienced quite often.

Table 4. Reasons for Applying Violence

\section{Reason for violence}

Not liking doctor's diagnosis/intervention

Not caring enough for the patient

Late arrival of the ambulance

Cautioning the relatives of the patient

Death of the patient

No reason

Other

\section{Number $\quad \%$}

$\begin{array}{rr}9 & 26,5 \\ 5 & 14,7 \\ 3 & 8,8 \\ 3 & 8,8 \\ 2 & 5,9 \\ 9 & 26,5 \\ 3 & 8,8\end{array}$

$34 \quad 100,0$

TOTAL

Everyone may have some positive or negative hospital experience. The last event that prompts people to commit violence may also cause them to remember previous negative 
experiences, which may lead to their anger to rise exponentially higher and get directed at the nearest security staff around at that moment.

Use of Metaphors: The language used in the reporting of news about violence on health personnel is seen to be sensational and tabloidized. Metaphors are used often and to rouse curiosity and interest such following descriptions are given: Public (severe) beating, harassment from intoxicated family doctor, 112 Help, female doctor, attack with a razor, assault by a drunk person, doctor not prescribing a medication, attack with a cleaver, assault on a female 112 worker, assault again, attack with a gyro blade, sounding the horn at sheep, attack with Molotov, attack by slapping, all-out attack, another attack, ugly attack, assault with weapon, assault with sword, assault with cleaver, attack again...

Some metaphors used in the analyzed news additionally demonstrate gender discrimination: Female doctor, assault on female 112 workers, and attack on female doctor with bowie knife... Also, in some metaphors used the scale of the violence is underscored: Molotov attack, slap attack, sword attack, gyro blade attack...

\section{CONCLUSION}

People learn about the current events about the world, including violence in the field of health, through mass communication media. However, the violence is emphasized in the produced reality of the violent cases in news. Yet, the news texts do not mention that the violence they report is a reflection of the health policies of that country or the various hardships people have to endure. Since the language of the news is sensational and tabloidized, violence is not perceived as a problem by the public and is not seen as an attitude and behavior that is alarming or something to be avoided. Furthermore, because the news do not draw attention to the connection between violence and punishment, it is perceived as a practicable and unpunishable action by people prone to violence. 


\section{References}

Annagür, B. (2010). Sağlık Çalışanlarına Yönelik Şiddet: Risk Faktörleri, Etkileri, Değerlendirilmesi ve Önlenmesi. Psikiyatride Güncel Yaklaşımlar - Current Approaches in Psychiatry, 2(2):161- 173

Atabek, N. (1994). Gazetecilikte Tarafsızlık. Marmara İletişim Dergisi, 7: 23-36.

Aydın, M. (2008). Isparta-Burdur Sağlık Çalışanlarına Yönelik Şiddet ve Şiddet Algisl. Isparta: Türk Tabipler Birliği Isparta-Burdur Tabip Odası Başkanlığı.

Ayranc1,Ü.,Yenilmez, Ç., Günay, Y., \&Kaptanoğlu, C. (2002). Çeşitli sağlık kurumlarında ve sağlık meslek gruplarında şiddete uğramasıklığı. Anadolu Psikiyatri Dergisi, 3:147154.

Barrett, S. (1997). Protecting against workplace violence; protection for workers to be given by the federal, state, and local governments, Public Management, 79(8), 9.

Baytar, O. (2004). Yazılı Basın Haberlerinde GörülenYapısal Sorunlar. Medya Eleştirileri (N.T. Akbulut, edi.). İstanbul: Beta

Bertrand, J.C. (2004). Medya Etiği. (Basın-Yayın Enformasyon Genel Müdürlüğü, çev.), Ankara.

Dursun, Ç. (2003). Haber vehabercilik/ gazetecilik üzerine düşünmek. Gazetecilikv ehabercilik (S. Alankuş, der.). İstanbul: IPS İletişim Vakfi.

Dursun, Ç. (2004). Haber, hakikat v eiktidar ilişkisi. Ankara: Elips Kitap.

Elliott PP.(1997).Violence in health care: What nurse managers need to know .Nursing Management, 28(12): 38-41.

Erkol, H., Gökdoğan, M.R., Erkol, Z., Boz, B. (2007). Aggression and violence towards health careproviders--a problem in Turkey? J Forensic Leg Med., 14:423-428.

Ergur, A. (2009). İnsanve Şiddet, Hekime Yönelik Şiddet Çalıştayı, (Hasan Oğan, yayına hazırlayan). İstanbul: TTB, İstanbul Tabip Odası.

Gates, D.M. (1995). Workplace violence. Gates, D. M. 1995. Workplace Violence. AAOHN J.,43: 536-543.

Hall, S. (1999). İdeolojininYeniden Keşfi: Medya Çalışmalarında Baskı Altında Tutulanın Geri Dönüşü. Medyave İktidar (M. Küçük, çev.) İstanbul: ArkYayınevi.

İlhan, M. N., \& at al. (2009). Gazi Üniversitesi Tıp Fakültesi Hastanesinde Çalışan Araştırma Görevlilerive İntern Doktorlarda Şiddete Maruziyet ve Şiddetle İlişkili Etmenler. Toplum Hekimliği Bülteni. 28(3):15-24. 
İnal, A. (1995). Yazılı basın haberlerinde 'yapısal' yanlılık sorunu. Toplum ve Bilim.67: 114134.

İnal, A. (1996). Haberi okumak. İstanbul: TemuçinYayınları.

İrvan, S. (1995). Demokratik Sistemde Medyanın Rolü. Birikim, 68-69:76-83.

Işık, M. (2002). Kitleiletişim sistemleri. Konya: Eğitim Kitabevi.

Kaya, A. R. (1985). Kitleiletişim sistemleri. Ankara: Teori Yayınları.

McLaren, K. (2011). Duyguların Dili, (Z. Yalçınkaya, çev.). İstanbul: Butik yayıncılık.

Özcan, N.K. \& others. (2011). Türkiye'de Sağlık ÇalışanlarınaYönelik Şiddet: Sistematik Derleme, Journal of Medical Sciences, 31(6):1442-1456.

Özer, Ö.(2010). Liberal Basın. İstanbul: Literatürk.

SağlıkSen (2013) Sağlık Çalışanları Şiddet Araştırması. http://www.sagliksen.org.tr/ (erişim tarihi: 15.02 .2015 ) 